\title{
Analisis Perubahan Atas Undang-Undang NOMOR 22 TAHUN 2001 TENTANG MINYAK DAN GAS BUMI
}

\author{
Indah Dwi Qurbani ${ }^{1}$
}

\begin{abstract}
Abstrak
UU No. 22 Tahun 2001 tentang Migas dianggap belum cukup memadai sebagai instrumen hukum yang dapat melindungi hak rakyat secara keseluruhan sebagaimana yang diamanatkan pasal 33 UUD Tahun 1945. Perubahan atas UU No. 22 Tahun 2001 tentang Migas perlu dilakukan dengan membuat terobosan hukum agar semangat melindungi kepentingan bangsa dan negara seperti diamanatkan dalam putusan Mahkamah Konstitusi No. 36/PUU-X/2012 dapat dipenuhi.
\end{abstract}

Kata kunci : perubahan, minyak dan gas bumi.

\section{Abstract}

The Act Number 22 Year 2001 about Oil and Gas assummed as uncomplite instrument to protect economic civil right, as Indonesian philosophical system base on 33 section of UUD year 1945. Based on the case The rule breaking in amandment Act Number 22 Year 2001 about Oil and Gas must fulfill the regulatory 36/PUU-X/2012, the state as a representation of the people in the control of natural resources should have the discretion to make rules that benefit the overall prosperity of the people.

Key words: amandment, oil and gas.

\section{Pendahuluan}

\subsection{Latar Belakang}

Data Bank Dunia dalam World Development Indicators ${ }^{2}$ menyebutkan, ratarata negara kaya sumber daya alam salah satunya minyak dan gas bumi

\footnotetext{
${ }^{1}$ Dosen Bagian Hukum Tata Negara, Fakultas Hukum Universitas Brawijaya Malang; Kandidat Doktor Ilmu Hukum Unair menulis disertasi “Prinsip Hukum Perimbangan Dana Bagi Hasil Migas."
} 
(selanjutnya disebut migas) memiliki performa ekonomi lebih buruk ketimbang negara-negara dengan anugerah sumber daya migas yang lebih sedikit. Hal ini cukup bertentangan dengan apa yang seharusnya terjadi. Negara-negara kaya migas kerap terjebak dalam ketimpangan, negara kaya dengan penduduk miskin.

Michael Ross juga menemukan adanya kecenderungan koreksi antara pemerintah yang opresif dengan kekayaan sektor ekstratifnya. Ross menemukan bahwa di negara-negara kaya minyak, gas dan mineral aplikasi pajak yang rendah dan pendapatan yang tinggi dibarengi oleh tingkat pendidikan masyarakat yang rendah dan struktur tenaga kerja yang belum terspesialisasi menyebabkan masyarakat kurang menghargai institusi perwakilan rakyat. Pendapatan negara yang besar memberikan kemampuan pada pemerintah untuk menghindari tekanan kaum demokrat dan menahan munculnya kaum tengah yang kritis. Studi yang dilakukan anggota OPEC pada kisaran tahun 1965 hingga tahun 1998 memperlihatkan bahwa Produk Nasional Bruto (gross national product) per kapita mereka turun rata-rata sebesar 1,3\% per tahun, sementara negara-negara berkembang non minyak naik sebesar 2,2\% dalam periode yang sama. ${ }^{3}$

Kenaikan harga Bahan Bakar Minyak (BBM) dalam lima tahun terakhir, telah berdampak cukup signifikan pada kehidupan rakyat Indonesia. Harga kebutuhan pokok naik, transportasi tampil dengan harga baru, seiring dengan jumlah pasokan BBM yang semakin menyusut (blank spot). Akibatnya antrian panjang terjadi dimana-mana. Ironisnya antrian BBM tersebut justru marak di daerah-daerah penghasil migas seperti Riau, Sumatera Selatan, Kalimantan Timur, Indramayu, Bekasi, Madura, dan beberapa daerah penghasil di 32 (tiga puluh dua) blok migas di Jawa Timur. ${ }^{4}$ Ketidakstabilan harga minyak mengakibatkan sulitnya pengambilan keputusan untuk mengelola secara efektif. Ketidakstabilan harga berdampak negatif pada disiplin anggaran, pengawasan terhadap keuangan publik, dan upaya perencanaan negara. Hal tersebut juga dikaitkan secara negatif dengan investasi, perbaikan distribusi pendapatan dan pengentasan kemiskinan. ${ }^{5}$

2Joseph E. Stiglitz, Menjadikan Sumber Daya Alam Sebagai Berkah, Bukan Kutukan,Svetlana Tsalik (eds), Covering Oil, Pantau Open Society Institute, New York, 2007, hlm. 17.

3 Terry Lynn Karl, Memahami Kutukan Sumber Daya Alam, Ibid, hlm; 32.

${ }^{4}$ HCB. Dharmawan dan Al Soni (Editor), BBM Antara Lahan Hidup dan Lahan Korupsi, Penerbit Buku Kompas, Jakarta, 2005, hlm; 21.

5 Terry Lynn Karl, op.cit, hlm; 32-33. 
Hal tersebut semakin menguatkan pendapat bahwa demokrasi ekonomi yang dicita-citakan di dalam Pasal 33 Undang-Undang Dasar Negara Republik Indonesia (selanjutnya disebut UUD NRI Tahun 1945) telah dinihilkan oleh penyelenggara negara, dengan memberikan kesempatan sebesar-besarnya kepada pemilik modal untuk mengeksploitasi migas, yaitu dengan cara merevisi segala peraturan perundang-undangan yang mengatur tentang pengelolaan migas untuk mengundang investasi pemilik modal, walaupun peraturan perundang-undangan tersebut bertentangan dengan falsafah dasar bangsa Indonesia, sehingga dapat diperkirakan, sedikit demi sedikit terjadi pelucutan kewenangan negara untuk diserahkan kepada pemilik modal dan Indonesia masuk dalam perangkap rekolonisasi. Hal tersebut sebagaimana termaktub dalam Pasal 28 ayat (2) Undang-Undang Nomor 22 Tahun 2001 tentang Minyak dan Gas Bumi (selanjutnya disebut UU Migas) yang mengutamakan mekanisme persaingan usaha dan tidak menjamin makna prinsip demokrasi ekonomi sebagaimana diatur dalam Pasal 33 ayat (4) UUD NRI Tahun 1945, oleh karena itu pasal tersebut dinyatakan bertentangan dengan UUD NRI Tahun 1945 oleh Mahkamah Konstitusi. ${ }^{6}$

Namun, bergantinya beberapa penyelenggara negara yang menjadi pemegang otoritas negara sama sekali tidak mencerminkan penghentian terhadap liberalisasi migas. Eksploitasi migas semakin tak tertanggulangi, aturan kontrak yang dikeluarkan demi keuntungan investasi semata. Indonesia sebagai salah satu koloni sumber daya energi dan pasar konsumsi tak terhindarkan telah digeser pada globalisme dan imperialisme Mutakhir. Dengan proyek pembukaan pasar, privatisasi dan intervensi konsumen energi, dalam konteks semacam ini mega proyeknya adalah pada pendudukan ekonomi sumber daya alam, aset-aset vital perekonomian dan penguasaan pasar lokal oleh perusahaan asing. ${ }^{7}$

6 Putusan Mahkamah Konstitusi Nomor 002/PUU-I/2003 atas permohonan judicial review terhadap Undang-Undang Nomor 22 Tahun 2001 Tentang Minyak dan Gas Bumi atas UUD NRI Tahun 1945 dimuat dalam berita Negara Republik Indonesia No. 01 Tahun 2005.

7 Indah Dwi Qurbani, Politik Hukum Pengelolaan Minyak dan Gas Bumi di Indonesia, Arena Hukum Jurnal Ilmu Hukum Universitas Brawijaya, Volume 6, Nomor 2, Agustus 2012, hlm. 116. Data penunjangnya adalah berlakunya Undang-Undang Nomor 25 tahun 2007 Tentang Penanaman Modal, dalam Pasal 1 dinyatakan tidak ada lagi perbedaan antara modal asing dan modal dalam negeri hal ini juga dipertegas di dalam Pasal 6 bahwa: "Pemerintah memberikan perlakuan yang sama kepada semua penanam modal yang berasal dari negara manapun yang melakukan kegiatan penanaman modal di Indonesia." Pasal 8 ayat (3) juga memberikan hak kepada penanam modal untuk melakukan transfer dan repatriasi dalam valuta asing sehingga praktis tidak ada lagi yang tidak boleh ditransfer ke negara asalnya. Pasal 22 juga mengatur hak atas tanah menjadi 95 tahun untuk Hak Guna Usaha, 80 tahun untuk Hak Guna Bangunan dan 70 tahun untuk Hak Pakai, pasal ini jelas semakin menghapus peran dan kewajiban pemerintah dalam pemenuhan kebutuhan akan hajat hidup orang banyak. 
Absurditas permigasan Indonesia dapat dilihat dalam beberapa kasus kontrak migas dimana kasus-kasus tersebut saling berkaitan laksana mata rantai saling sambung menyambung menuju kehancuran pengelolaan migas di Indonesia jika tidak berhati-hati. UU Migas yang diharapkan dapat memberi landasan hukum baru bagi langkah-langkah pembaruan dan penataan kembali usaha migas dengan mengganti UU sebelumnya yaitu UU No. 8 Tahun 1971 tentang Pertamina, ternyata sarat dengan agenda tersembunyi (hidden agenda). ${ }^{8}$

Realitas tersebut tidak sejalan dengan prinsip transparansi dalam pengelolaan migas, karena dengan standar transparansi dan akuntabilitas yang tinggi dapat memberikan manfaat bagi kepentingan dan kesejahteraan rakyat serta membawa peningkatan pengelolaan lingkungan.

Berdasarkan hal tersebut UU migas dianggap belum cukup memadai sebagai instrumen hukum yang dapat melindungi hak rakyat secara keseluruhan sebagaimana yang diamanatkan pasal 33 UUD NRI Tahun 1945. Hal ini juga dapat dibuktikan dengan diajukannya permohonan judicial review kepada Mahkamah Konstitusi (MK) hingga tiga kali terhadap UU migas dengan putusan pada tahun 2004, tahun 2007 dan tahun 2012. ${ }^{9}$

Masalah lainnya seperti politik membuat Negara penghasil migas biasanya rawan terhadap kegagalan kebijakan. Karena Negara menjelma menjadi "pot madu" yang cenderung digunakan demi kepentingan kekuasaan dan meluaskan korupsi. Sebagai kelompok, Negara-negara pengekspor migas lebih korup ketimbang Negara-negara lain di dunia (bahkan bila Norwegia dan Kanada dimasukkan). Nigeria, Angola, Azarbaizan, Kongo, Kamerun, dan Indonesia bersaing posisi "paling korup" dalam ranking tahunan yang dirilis Transparency International. Tingkat korupsi yang tinggi semakin memperbesar kegagalan dalam pengelolaan migas.

Berdasarkan hal tersebut artikel ini lebih menekankan pada analisa hukum model rule breaking (terobosan hukum) dalam menganalisis perubahan atas UU migas (selanjutnya disebut RUU migas), yaitu sebuah metode yang

Pengadaan yang membutuhkan dana besar diserahkan kepada swasta, namun karena yang punya modal besar hanya investor asing maka pengadaannya menjadi monopolistik.

'Indah Dwi Qurbani, Proses Terbentuknya Undang-Undang Nomor 22 Tahun 2001 tentang Minyak dan Gas Bumi dalam Prespektif Politik Demokratis, Skripsi Program Sarjana Fakultas Hukum Universitas Muhammadiyah Malang, 2003, tidak dipublikasikan, hlm. 15.

9 Pada saat pengucapan Putusan, terdapat sekitar 350 Production Sharing Contract senilai \$US 70 milyar per tahun, yang menyumbangkan kurang lebih Rp. 360 Triliun terhadap pendapatan negara. Dalam Simon Butt dan Fritz Edward Siregar, Analisis Kritik Terhadap Putusan Mahkamah Konstitusi Nomor 36/PUU-X/2012, Mimbar Hukum Volume 25, Nomor 1, Februari 2013, hlm. 2. 
melompat dari alur hukum konvensional. Model semacam ini dibenarkan dalam ilmu hukum dan terjadi di Hooge Raad (MA) Belanda ketika membuat putusan revolusioner tentang makna onrectmatig (melawan hukum) dalam onrechtmatige daad (perbuatan melawan hukum). ${ }^{10}$ Karl Renner menegaskan the development of the law gradually work out what is socially reasonable. ${ }^{11}$

Terobosan hukum dimaksudkan bahwa terdapat hubungan yang erat antara perencanaan hukum, penyusunan hukum, penegakan hukum dan pendayagunaan hukum yaitu untuk kesejahteraan rakyat, sehingga ada pergeseran paradigma dari teknokratis struktural kearah hukum yang bersifat humanis partisipatoris. Hal tersebut tidak dapat didekati dengan studi hukum yang konvensional yaitu hukum bukan untuk hukum itu sendiri melainkan dibutuhkan optik yang lebih mampu "menggambarkan" hukum dalam keadaan yang "sebenarnya" dan selengkapnya (the truth about law). ${ }^{12}$

Berdasarkan hal tersebut analisis dilakukan dengan menggunakan 2 (dua) metode pendekatan yaitu: 1) Pendekatan perundang-undangan (statute approach) dengan menelaah peraturan perundang-undangan ${ }^{13}$ yang berkaitan dengan pengelolaan migas; 2) Pendekatan konsep (conceptual approach), yaitu dengan menelaah dan memahami konsep-konsep pengelolaan migas ${ }^{14}$ sehingga tidak menimbulkan pemahaman yang multitafsir dan kabur mengenai konsep pengelolaan migas. Hal ini dilakukan agar semangat melindungi kepentingan bangsa dan negara dapat dipenuhi. Dengan demikian, terdapat proporsionalitas antara ruang bagi investor migas dan pemenuhan sebesarbesarnya untuk kemakmuran rakyat.

\section{Pembahasan}

\subsection{Proses Terbentuknya UU Migas}

10 Tim Justice for The Poor-The World Bank, Menciptakan Peluang Keadilan: Laporan Atas Studi Village Justice in Indonesia dan Terobosan dalam Penegakan Hukum di Tingkat Lokal, The World Bank, Jakarta, 2004.

11 Satjipto Rahardjo, Pokok-Pokok Pikiran Memberantas Korupsi Secara Progresif, Anti Corruption Summit, Badan Kerjasama Fakultas Hukum Seluruh Indonesia, Universitas Gajah Mada, Yogyakarta, 11-13 Agustus 2005. hlm; 7-8.

12 Suratman dan Philips Dillah, Metode Penelitian Hukum, Alfabeta, Bandung, 2013,

13 Peter Mahmud Marzuki. Penelitian Hukum. Jakarta: Kencana. 2007. hlm. 96.

14 Johnny Ibrahim. Teori dan Metodologi Penelitian HukumNormatif. Malang: Bayumedia. 2007 hlm. 391. 
Sektor Migas merupakan sektor yang sangat strategis di masa lampau, masa kini maupun di masa yang akan datang dilihat dari segi kontribusinya terhadap Anggaran Pendapatan dan Belanja Negara (disingkat APBN), penerimaan devisa dan sebagainya. Kontribusi ini diperkirakan akan berkurang di masa mendatang mengingat semakin menipisnya proven reserves minyak bumi Indonesia. Produksi minyak tahunan lebih besar dibandingkan dengan penemuan cadangan (reserves) minyak baru, yang menyebabkan cadangan minyak Indonesia terus turun. Akhir tahun 2011 jumlah cadangan minyak Indonesia sekitar 4 milyar barrel, turun sebesar 4,76 \% dari cadangan tahun sebelumnya sebesar 4,2 milliar barrel. Turunnya cadangan tersebut dikarenakan jumlah minyak yang terproduksi (production) tahun 2011 sebesar 343,83 juta barrel, sedangkan penemuan cadangan minyak baru (new reserve development) 143,83 juta barrel. ${ }^{15}$ Oleh karena itu, dibutuhkan pengaturan terkait dengan pengusahaan migas.

Berikut ini ádalah peraturan perundang-undangan yang mengatur tentang migas pasca Indische Mijn Wet ${ }^{16}$ yang dimulai sejak tahun 1960:

1. UU No. 44 Prp Tahun 1960 Tentang Pertambangan Minyak dan Gas Bumi (Lembaran Negara Tahun 1960 Nomor 133, Tambahan Lembaran Negara Nomor 2070);

2. UU No. 8 Tahun 1971 Tentang Perusahaan Pertambangan Minyak Negara (Pertamina) Lembaran Negara Tahun 1971 Nomor 76, Tambahan Lembaran Negara Nomor 2971;

3. UU No. 22 Tahun 2001 Tentang Minyak dan Gas Bumi (Lembaran Negara Tahun 2001 Nomor 136 Tambahan Lembaran Negara Nomor 4152);

Perkembangan dan perubahan peraturan perundang-undangan migas tersebut menunjukkan peranan migas terhadap perekonomian Indonesia sangat besar, sehingga investasi dalam pengelolaan migas adalah aset yang harus dilindungi. Investasi migas mendukung pertumbuhan ekonomi dan pemasukan kas negara melalui pajak dan royalti yang dibayarkan yang selanjutnya didistribusikan untuk kesejahteraan rakyat.

15 Zulkifli Rangkuti dan Untung Suryanto, Pemanfaatan Dana Migas (Migas Fund) untuk Ketahanan energi (Energy Security) sebagai alternatif Pengembangan Industri Hulu (UpStream) Migas Nasional, http://works.bepress.com/drzulkifli_rangkuti/10, diakses tanggal 1 Desember 2013.

16 Indische Mijn Wet merupakan aturan yang mengatur tentang pengusahaan pertambangan termasuk minyak bumi pada zaman pemerintahan kolonial Belanda. 
Namun, pemerintah selama ini selalu berkelit dengan ketidakmampuan dalam hal investasi dan mandulnya teknologi untuk mengelola sendiri sumber daya migas. Sehingga yang terjadi adalah penguasaan secara semu, ketika secara definitif migas sebagai hak rakyat yang dititipkan dan diserahkan kepada negara untuk dikelola dan dimanfaatkan untuk kesejahteraan rakyat kenyataannya berbeda dengan aplikasi di lapangan, energi yang dititipkan beralih pada kekuasaan pemilik modal yang berlindung pada argumentasi technical barrier, hi-tech, padat modal dan resiko tinggi.

Restrukturisasi ekonomi yang ditandai dengan privatisasi dan deregulasi di berbagai sektor ekonomi, termasuk infrastruktur, menjadi gelombang yang dalam 2 (dua) dekade belakangan telah melanda banyak negara berkembang. Reformasi pasar energi, khususnya di bidang migas, menjadi agenda yang telah dipraktekkan di sejumlah negara berkembang di Asia, Amerika Latin, bahkan Afrika. Restrukturisasi sektor ekonomi pada umumnya dimaksudkan untuk menghasilkan kinerja sistem ekonomi yang lebih efisien, terbuka, adil, menghasilkan manfaat yang lebih besar bagi masyarakat dan lingkungan. ${ }^{17}$

Pada awalnya UU migas terdiri dari 15 bab dan 67 pasal.Dalam konsiderans, UU migas dimaksudkan untuk menciptakan kegiatan usaha migas yang "mandiri, transparan, berdaya saing, berwawasan pelestarian lingkungan, serta mendorong perkembangan potensi dan peranan nasional." dan di dalamnya memuat 9 (sembilan) pokok pikiran yaitu:

Pertama, migas sebagai sumber kekayaan alam yang terkandung dalam wilayah hukum pertambangan Indonesia dikuasai negara dan diselenggarakan oleh pemerintah sebagai pemegang Kuasa Pertambangan. Kuasa Pertambangan tetap dipegang oleh pemerintah agar pemerintah dapat mengatur, memelihara dan menggunakan kekayaan nasional tersebut untuk sebesar-besar kemakmuran rakyat. Selanjutnya pemerintah membentuk Badan Pelaksana.

Kedua,menghilangkan usaha yang bersifat monopoli baik di sektor hulu dan hilir. Dalam bidang usaha hulu yang terdiri dari eksplorasi dan eksploitasi yang merupakan kegiatan berkaitan dengan pengurasan kekayaan alam berupa bahan galian migas, pihak swasta hanya dapat melakukan kegiatan pengusahaan migas secara tidak langsung yaitu sebagai kontraktor melalui kerja sama dengan Badan Pelaksana. Di bidang usaha hilir yang terdiri dari

\footnotetext{
17 Hanan Nugroho, Deregulasi Setengah Hati: Tinjauan Terhadap Restrukturasi Sektor Energi Indonesia, Seminar Akademik Tahunan Ekonomi I, Pasca Sarjana Ekonomi Universitas Indonesia \& Ikatan Sarjana Ekonomi Indonesia, Jakarta, 8-9 Desember 2004, hlm. 3.
} 
usaha pengolahan, pengangkutan, penyimpanan, dan niaga dapat dilaksanakan oleh perusahaan berdasarkan izin usaha yang dikeluarkan oleh pemerintah.

Ketiga, menciptakan dan menjamin penerimaan pusat dan penerimaan daerah yang lebih nyata dari hasil produksi, sehingga penerimaan negara dari sektor migas dapat dinikmati secara langsung oleh rakyat di daerah yang bersangkutan. Untuk maksud tersebut perusahaan atau bentuk usaha tetap wajib menyerahkan bagian negara, pungutan negara, membayar bonus, pajakpajak, pajak daerah dan retribusi daerah, serta kewajiban kepabeanan yang berlaku. Atas pungutan negara, bagian negara dan bonus diperuntukkan sebagai penerimaan pusat dan daerah.

Keempat, menumbuh kembangkan perusahaan nasional migas di dalam maupun di luar negeri serta dapat mengakomodir perkembangan kegiatan usaha migas yang akan datang. Di samping juga memberikan apresiasi yang lebih besar terhadap pemanfaatan barang dan jasa, kemampuan rekayasa dan rancang bangun dalam negeri.

Kelima, memberikan ketentuan yang lebih jelas tentang jaminan kelangsungan atas penyediaan dan pelayanan BBM sekaligus pengaturan yang berkaitan dengan mekanisme subsidi BBM.

Keenam, menjamin penyediaan data yang cukup, tenaga kerja profesional, peningkatan fungsi penelitian dan pengembangan serta menggiatkan investasi melalui penciptaan iklim investasi yang kondusif.

Ketujuh, terdapatnya pengaturan pengelolaan wilayah kerja oleh pemerintah yang akan diusahakan oleh perusahaan atau badan usaha tetap dan untuk penyediaan lahan guna menunjang penetapan wilayah kerja tersebut, pemerintah dapat melaksanakan survei umum sebagai upaya meningkatkan nilai lahan yang ditawarkan kepada para peminat.

Kedelapan, adanya jaminan kepastian hukum, yang lebih mantap (pengaturan yang sederhana, tegas dan konsisten) serta menghilangkan campur tangan pemerintah yang terlalu besar, sehingga iklim usaha diharapkan dapat lebih sehat dan kompetitif.

Kesembilan, terwujudnya antisipasi pencegahan dan penanggulangan meningkatnya tindak pidana dalam kegiatan usaha migas baik secara kuantitas melalui pengangkatan penyidik Pegawai Negeri Sipil (PNS).

9 (sembilan) pokok pikiran tersebut dituangkan dalam Alur pikir pengembangan industri migas nasional sebagaimana dalam bagan di bawah ini 


\section{Bagan 1.}

\section{Alur pikir Pengembangan Industri Migas Nasional Berdasarkan}

UU Nomor 22 Tahun 2001

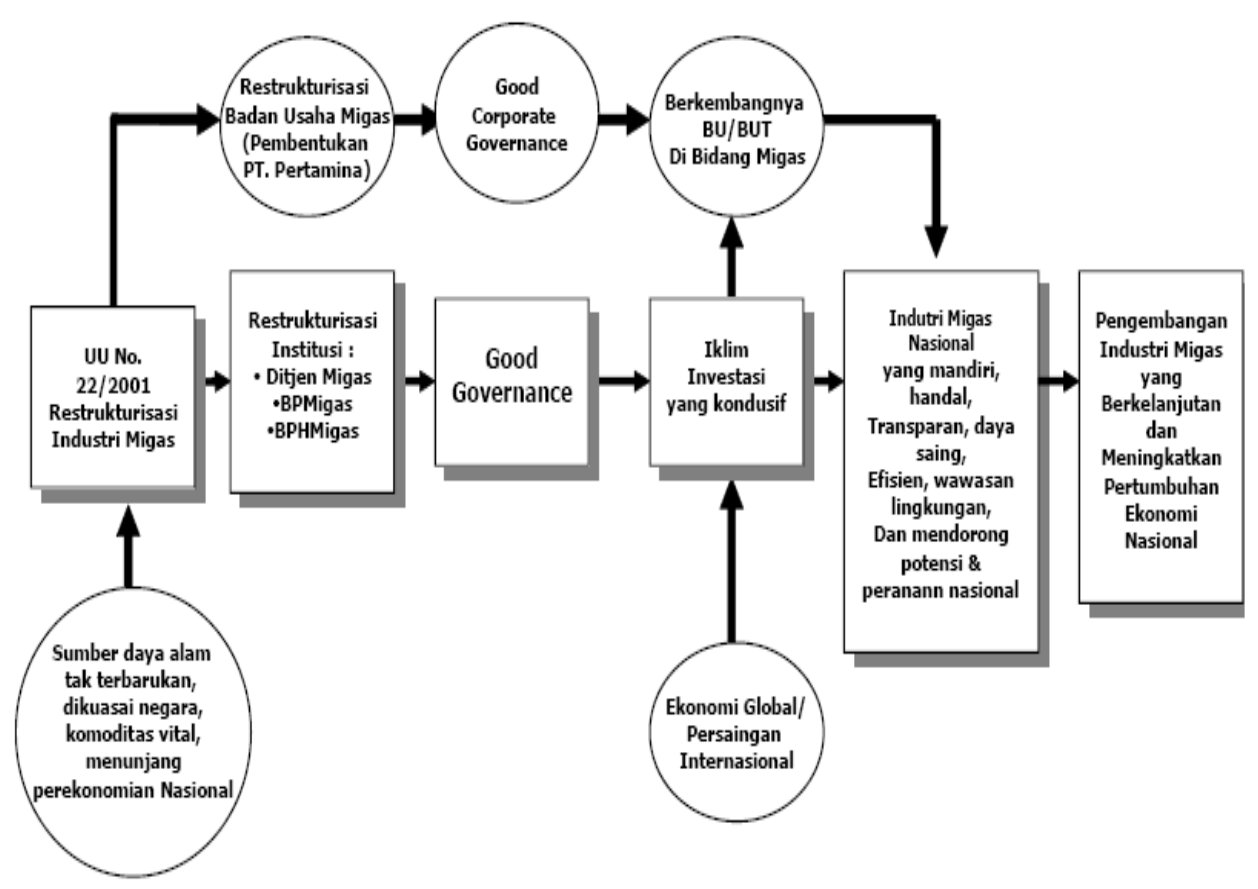

Sumber; Pedoman dan Pola Tetap Pengembangan Industri Migas Nasional 2005-2020, Blue Print UU Nomor 22 Tahun 2001 Tentang Migas, Kementerian Energi dan Sumber Daya Mineral.

\subsection{Fakta Hukum}

Namun, sejak diberlakukannya UU migas pada tahun 2001, UU migas dipandang beberapa kalangan memiliki sejumlah titik lemah yang merugikan kepentingan nasional antara lain :

\section{Tabel 1}

\section{Pasal Bermasalah dalam UU migas}




\begin{tabular}{|c|c|c|}
\hline No. & $\begin{array}{c}\text { UU No. } 22 \\
\text { Tahun } 2001\end{array}$ & Permasalahan \\
\hline 1. & Pasal 1 angka 5 & $\begin{array}{l}\text { Definisi Kuasa Pertambangan, hanya dibatasi pada } \\
\text { kegiatan eksplorasi dan eksploitasi saja seperti } \\
\text { dinyatakan: "Kuasa Pertambangan adalah wewenang } \\
\text { yang diberikan negara kepada Pemerintah untuk } \\
\text { menyelenggarakan kegiatan eksplorasi dan } \\
\text { eksploitasi." Masalah yang menyangkut pemurnian } \\
\text { atau pengilangan, pengangkutan dan penjualan BBM } \\
\text { tidak termasuk di dalam rangkaian kuasa } \\
\text { pertambangan dan oleh karenanya tidak termasuk di } \\
\text { dalam wewenang yang diberikan oleh negara kepada } \\
\text { Pemerintah. Padahal hingga saat ini, BBM masih } \\
\text { merupakan cabang produksi penting bagi negara dan } \\
\text { menguasai hajat hidup orang banyak. }\end{array}$ \\
\hline 2. & Pasal 4 ayat (2) & $\begin{array}{l}\text { Dalam bidang usaha Hulu migas, ditentukan bahwa } \\
\text { Penguasaan oleh negara sebagaimana dimaksud dalam ayat } \\
\text { (1) diselenggarakan oleh Pemerintah sebagai pemegang } \\
\text { Kuasa Pertambangan. Negara akan menguasai } \\
\text { sumberdaya yang masih bersifat abstrak dan belum } \\
\text { terbukti kandungan hydrocarbonnya apalagi volume } \\
\text { Migas-nya. karena kuasa pertambangan tersebut } \\
\text { dilimpahkan oleh Pemerintah cq. Menteri kepada } \\
\text { Badan Usaha dan Badan Usaha Tetap untuk tiap-tiap } \\
\text { Wilayah Kuasa. }\end{array}$ \\
\hline 3. & Pasal 12 ayat (3) & $\begin{array}{l}\text { Kuasa pertambangan yang cakupannya sudah } \\
\text { menjadi sangat sempit oleh Menteri ESDM justru } \\
\text { diserahkan kepada orang-seorang/pelaku usaha. } \\
\text { "Menteri menetapkan Badan Usaha dan Bentuk Usaha } \\
\text { Tetap yang diberi wewenang melakukan kegiatan usaha } \\
\text { eksplorasi dan eksploitasi pada wilayah kerja sebagaimana } \\
\text { dimaksud dalam ayat (2)." Penyerahan Kuasa } \\
\text { pertambangan kepada pemain/perusahaan akan } \\
\text { menghilangkan kedaulatan negara di dalam mengatur } \\
\text { kegiatan pengelolaan dan pengusahaan Migas } \\
\text { disektor Hulu dan sangat mirip dengan Sistem }\end{array}$ \\
\hline
\end{tabular}




\begin{tabular}{|c|c|c|}
\hline & & Konsesi "Kontrak 5a" Indische Mijn Wet. \\
\hline 4. & Pasal 21 ayat (1) & $\begin{array}{l}\text { Adanya status hukum Badan Pelaksana yang bukan } \\
\text { badan usaha seperti investor sehingga bertambahnya } \\
\text { birokrasi berupa persetujuan Menteri untuk } \\
\text { pengembangan lapangan pertama serta konsultasi } \\
\text { dengan Pemda untuk keperluan kesesuaian dengan } \\
\text { tata ruang daerah, dan adanya Domestic market } \\
\text { Obligation (DMO) gas bumi. }\end{array}$ \\
\hline 5. & Pasal 23 ayat (1) & $\begin{array}{l}\text { "Kegiatan Usaha Hilir sebagaimana dimaksud dalam } \\
\text { Pasal } 5 \text { angka 2, dapat dilaksanakan oleh Badan Usaha } \\
\text { setelah mendapat Izin Usaha dari Pemerintah"; Melalui } \\
\text { pengaturan dalam bentuk ijin usaha ini jelas akan } \\
\text { sangat mudah bagi Badan Usaha manapun untuk } \\
\text { menerapkan praktek-praktek usaha yang liberal guna } \\
\text { mendahulukan kepentingan pengusaha-pengusaha } \\
\text { yang berorientasi pada maksimasi laba dan mereka } \\
\text { tidak akan memperhatikan kepentingan hajat hidup } \\
\text { orang banyak. }\end{array}$ \\
\hline 6. & Pasal 23 ayat (2) & $\begin{array}{l}\text { "Izin Usaha yang diperlukan untuk kegiatan usaha } \\
\text { Minyak Bumi dan/atau kegiatan usaha Gas Bumi } \\
\text { sebagaimana dimaksud dalam ayat (1) dibedakan atas: } \\
\text { "a. Izin Usaha Pengolahan, b. Izin Usaha } \\
\text { Pengangkutan, c. Izin Usaha Penyimpanan, d. Izin } \\
\text { Usaha Niaga." Badan usaha yang sudah mendapatkan } \\
\text { izin usaha sudah barang tentu akan mendahulukan } \\
\text { perolehan kembalian modal dan keuntungan usahanya } \\
\text { dan tidak akan pernah memperbaiki dan } \\
\text { mempertimbangkan produksi dengan keberpihakan } \\
\text { pada kepentingan masyarakat luas; }\end{array}$ \\
\hline 7. & Pasal 28 ayat (2) & $\begin{array}{l}\text { menyerahkan harga BBM sepenuhnya kepada } \\
\text { persaingan usaha }\end{array}$ \\
\hline 8. & Pasal 28 ayat (3) & $\begin{array}{l}\text { hanya menyangkut pemberian subsidi bagi golongan } \\
\text { masyarakat tertentu sebagai tanggung jawab sosial } \\
\text { Pemerintah, namun tidak secara eksplisit } \\
\text { menyebutkan bagaimana mengatur perbedaan harga } \\
\text { antar Daerah yang pasti akan timbul dengan }\end{array}$ \\
\hline
\end{tabular}




\begin{tabular}{|c|c|c|}
\hline & & $\begin{array}{l}\text { pemberlakukan harga BBM atas dasar persaingan } \\
\text { usaha. }\end{array}$ \\
\hline 9. & Pasal 31 & $\begin{array}{l}\text { mengandung ketidak pastian hukum merusak iklim } \\
\text { investasi sektor hulu migas, antara lain karena adanya } \\
\text { pembayaran bea masuk, pungutan atas impor dan } \\
\text { cukai, pajak/retribusi daerah, iuran eksplorasi dan } \\
\text { lainnya pada tahap eksplorasi. }\end{array}$ \\
\hline 10. & Pasal 31 ayat (4) & $\begin{array}{l}\text { dapatnya perlakuan pajak-pajak yang berbeda antar } \\
\text { kontrak kerja sama }\end{array}$ \\
\hline 11. & $\begin{array}{l}\text { Pasal } 44 \text { ayat }(3) \\
\text { huruf g. }\end{array}$ & $\begin{array}{l}\text { Menganut faham liberalisasi migas dengan penjualan } \\
\text { hasil Migas bagian negara yang kini dijualkan oleh } \\
\text { fihak pengusaha swasta dan asing. }\end{array}$ \\
\hline 12. & Pasal 60 a & $\begin{array}{l}\text { "Pada saat Undang-undang ini berlaku: a. dalam } \\
\text { jangka waktu paling lama } 2 \text { (dua) tahun, Pertamina } \\
\text { dialihkan bentuknya menjadi Perusahaan Perseroan } \\
\text { (Persero) dengan Peraturan Pemerintah", maka } \\
\text { terbukalah peluang untuk menjual atau mengalihkan } \\
\text { sebagian saham BUMN ini ke pihak orang seorang. }\end{array}$ \\
\hline 13. & Pasal 62 & $\begin{array}{l}\text { "Pada saat Undang-undang ini berlaku Pertamina } \\
\text { tetap melaksanakan tugas penyediaan dan pelayanan } \\
\text { Bahan Bakar Minyak untuk keperluan dalam negeri } \\
\text { sampai jangka waktu paling lama } 4 \text { (empat) tahun". } \\
\text { Hal ini sudah barang tentu membebani BUMN ini } \\
\text { secara berlebihan dan berpotensi mengurangi } \\
\text { kesempatan peningkatan kesejahteraan. }\end{array}$ \\
\hline 14. & Pasal 66 & $\begin{array}{l}\text { ketidak pastian kontrak-kontrak lama dengan tidak } \\
\text { berlakunya lagi Anggaran Dasar Pertamina/UU No. } 8 \\
\text { Tahun } 1971 \text { pada periode transisi }\end{array}$ \\
\hline
\end{tabular}

Sumber : diolah dari UU No. 22 Tahun 2001 tentang Migas

Pasal-pasal bermasalah tersebut yang kemudian segera setelah UU migas disahkan oleh pemerintah pada tanggal 23 November 2001, berbagai asosiasi seperti; Asosiasi Ahli-ahli Hukum, Organisasi perlindungan konsumen, 
berbagai Lembaga Swadaya Masyarakat (LSM) dan lain-lain mengajukan yudicial review (uji materiil) ke Mahkamah Konstitusi.

\section{Putusan Mahkamah Konstitusi No. 002/PUU-I/2003.}

Berdasarkan putusan tersebut Tiga pasal dalam UU migas yang bertentangan dengan UUD NRI Tahun 1945 menurut putusan Mahkamah Konstitusi, adalah:

1. Pasal 12 ayat (3) UU Nomor 22 Tahun 2001: "Menteri (ESDM) menetapkan Badan Usaha atau Badan Usaha tetap yang diberi wewenang melakukan kegiatan usaha Eksplorasi dan Eksploitasi pada Wilayah Kerja sebagaimana dimaksud dalam ayat (2)." Ini dapat berarti bahwa Badan Usaha atau Badan Usaha Tetap diberi wewenang kuasa pertambangan migas yang berada pada Menteri.

2. Pasal 22 ayat (1) UU Nomor 22 Tahun 2001: "Badan Usaha atau Badan Usaha tetap wajib menyerahkan paling banyak 25\% (dua puluh lima persen) bagiannya dari hasil produksi minyak bumi dan/atau gas bumi untuk memenuhi kebutuhan dalam negeri." Putusan Mahkamah Konstitusi adalah merubah kata-kata "paling banyak" menjadi "paling sedikit."

3. Pasal 28 ayat (2) UU Nomor 22 Tahun 2001: “Harga Bahan Bakar Minyak dan harga Gas Bumi diserahkan pada mekanisme persaingan usaha yang wajar dan sehat." Mahkamah Konstitusi memutuskan bahwa harga BBM dan gas bumi ditetapkan oleh pemerintah.

\section{Putusan Mahkamah Konstitusi No. 20/PUU-V/2007}

Amar putusan Mahkamah Kontitusi memutuskan, dengan mengingat Pasal 56 Ayat (1) Undang-Undang Nomor 24 Tahun 2003 Tentang Mahkamah Konstitusi (Lembaran Negara Republik Indonesia Tahun 2003 Nomor 98, Tambahan Lembaran Negara Republik Indonesia Nomor 4316); Menyatakan permohonan para Pemohon tidak dapat diterima (niet ontvankelijk verklaard).

Menurut Mahkamah Konstitusi, seandainya pun para Pemohon memiliki kedudukan hukum (legal standing), quod non, permohonan a quo juga tidak dapat dikabulkan, karena dengan dinyatakannya Pasal 11 ayat (2) UU Nomor 22 Tahun 2001 tidak mempunyai kekuatan hukum 
mengikat, justru tidak akan ada lagi ketentuan yang mengharuskan adanya pemberitahuan secara tertulis kepada DPR. Hal ini berarti akan lebih merugikan DPR sebagai lembaga maupun Anggota DPR.

\section{Putusan Mahkamah Konstitusi No. 36/PUU-X/2012}

Mahkamah Konstitusi melakukan pembubaran terhadap Badan Pelaksana Migas karena ketidaksesuaian dengan Undang-Undang yang berlaku. Mahkamah Konstitusi menyatakan frasa "dengan badan pelaksana" dalam Pasal 11 ayat (1), frasa "melalui badan pelaksana" dalam Pasal 20 ayat (3), frasa "berdasarkan pertimbangan dari badan pelaksana" dalam Pasal 20 ayat (3), frasa "berdasarkan pertimbangan dari badan pelaksana dan" dalam Pasal 21 ayat (1), frasa "badan pelaksana dan" dalam Pasal 49 UU Nomor 22 Tahun 2001 tentang Minyak dan Gas Bumi bertentangan dengan UUD 1945 dan tidak memiliki kekuatan hukum mengikat.

Mahkamah Konstitusi juga menyatakan bahwa Pasal 1 angka 23, Pasal 4 ayat (3), Pasal 41 ayat (2), Pasal 44, Pasal 45, Pasal 48 ayat (1), Pasal 59 huruf a, Pasal 61, dan Pasal 63 UU Nomor 22 Tahun 2001 tentang Minyak dan Gas Bumi bertentangan dengan UUD 1945 dan tidak mempunyai kekuatan hukum mengikat.

\subsection{Analisis Rancangan Perubahan Atas UU Migas}

Berdasarkan uraian dalam proses terbentuknya dan fakta hukum UU migas tersebut di atas,maka perlu segera dilakukan perubahan atas UU migas. Perubahan yang sangat mendesak antara lain :

1. Putusan MK No. 36/PUU-X/2012 harus menjadi acuan dalam perubahan atas UU migas. Mahkamah Konstitusi menimbang bahwa UU migas mengkonstruksikan hubungan antar negara dengan badan usaha yang melakukan pengelolaan migas dengan hubungan keperdataan dalam bentuk kontrak kerja sama (KKS). Menurut Mahkamah Konstitusi hubungan antara negara dengan swasta dalam pengelolaan migas tidak dapat dilakukan dengan hubungan keperdataan akan tetapi harus bersifat publik,18 yaitu berupa

18 Cut Asmaul Husna TR, Implikasi Putusan Mahkamah Konstitusi Terhadap Regulasi Production Sharing Contract, Jurnal Konstitusi Volume 9 Nomor 4, Desember 2012, hlm. 605606. 
pemberian konsesi atau perizinan yang sepenuhnya di bawah kontrol dan kekuasaan negara. Oleh sebab itu BP migas selaku Badan Hukum Milik Negara (disingkat BHMN) oleh Mahkamah Konstitusi dianggap bertentangan dengan prinsip penguasaan negara yang dimaksudkan oleh konstitusi. Mengacu pada putusan tersebut maka perubahan atas UU migas harus memuat tujuh ciri konstitusional sehingga amanat putusan MK Nomor 36/PUU-X/2012 dapat dilaksanakan, yaitu:

a. Perekonomian bertujuan untuk mencapai kemakmuran bersama seluruh rakyat, hal ini secara eksplisit dijelaskan dalam penjelasan Pasal 33 UUD 1945.

b. Keikutsertaan rakyat dalam pemilikan, proses produksi dan menikmati hasilnya.Hal ini sesuai dengan rumusan yang terdapat dalam Pasal 33 ayat (1) dan ayat (4) UUD 1945.

c. Sesuai dengan prinsip Pasal 33 ayat (4) UUD 1945 yaitu efisiensi berkeadilan, perekonomian perlu dijalankan dengan menggunakan mekanisme pasar yang berkeadilan yang didasarkan pada persaingan yang sehat dan peranan serta kewenangan negara untuk intervensi jika terjadi kegagalan pasar.

d. Keempat, peran Negara harus dijamin, sebagaimana diamanatkan Pasal 33 ayat (1) dan ayat (3) UUD 1945 terutama dalam hal perencanaan ekonomi nasional, dalam membentuk dan menegakkan pelaksanaan Undang-undang, dan dalam hal melaksanakan program pelayanan dan pemberdayaan masyarakat, pembebasan pajak, pemberian subsidi dan lainnya.

e. Badan Usaha Milik Negara (BUMN) sebagai salah satu soko guru kegiatan ekonomi menguasai cabang-cabang produksi yang penting dan yang menguasai hajat hidup orang banyak. Ini jelas tertuang dalam Pasal 33 ayat (2) UUD 1945.

f. Koperasi sebagai soko guru perekonomian rakyat harus diwujudkan dalam semangat kebersamaan dengan BUMN dan swasta, serta sebagai badan usaha ekonomi rakyat. 
g. Perekonomian nasional haruslah merupakan perwujudan dari kemitraan yang sejajar antara koperasi, BUMN dan swasta. Prinsip ini termuat dalam Pasal 33 ayat (1) UUD 1945.19

2. Dan, sebagai contoh pentingnya implementasi tujuh ciri konsitusional tersebut pada penjelasan nomor 1 adalah adanya pasal tambahan dalam rencana revisi UU migas dalam Bab IX Pasal 54, Pasal 55 dan Pasal 56 draf RUU migas ${ }^{20}$ terkait dana hasil pengusahaan migas (petroleum fund). Berikut isi rancangan pasalnya secara lengkap:

- Pasal 54 RUU migas

(1). Menteri, Menteri Keuangan, dan Badan Pengusahaan wajib mengusahakan dan mengelola dana minyak dan gas bumi secara bersamasama dalam sebuah rekening bersama secara transparan dan akuntabel.

(2). Dana minyak dan gas bumi sebagaimana dimaksud pada ayat (1) ditujukan untuk kegiatan yang berkaitan dengan penggantian cadangan minyak dan gas bumi, pengembangan energi terbarukan, dan untuk kepentingan generasi yang akan datang.

(3). Dana minyak dan gas bumi sebagaimana dimaksud pada ayat (1) bersumber dari presentase tertentu:

a. Hasil penerimaan kotor minyak dan gas bumi bagian negara;

b. Bonus-bonus yang menjadi hak pemerintah berdasarkan kontrak kerja sama dan Undang-Undang ini;

c. Pungutan dan iuran yang menjadi hak negara berdasarkan peraturan perundang-undangan yang berlaku.

- Pasal 55 RUU migas

Pengelolaan dana minyak dan gas bumi sebagaimana dimaksud dalam Pasal 54 wajib diperiksa oleh Badan Pemeriksa Keuangan Republik Indonesia dan Akuntan Publik.

- Pasal 56 RUU migas

19 Subiakto Tjakrawerdaja, 2007, Menunggu UU Induk Mengenai Perekonomian Nasional, Reform Review (Jurnal untuk Kajian dan Pemetaan Krisis), Volume II No. 1 April-Juni 2008, hal; 40 .

${ }^{20}$ Draft RUU Perubahan UU Migas, awal persidangan 2012 disusun oleh tim PUU Setjen DPR RI atas penugasan dari Komisi VII DPR RI. 
Ketentuan lebih lanjut mengenai dana minyak dan gas bumi sebagaimana dimaksud dalam Pasal 54 dan Pasal 55 diatur di dalam Peraturan Pemerintah $(P P)$.

Substansi dasar dalam ketiga pasal tersebut adalah agar pengelolaan dan pengusahaan dana migas digunakan untuk penggantian cadangan migas, pengembangan energi terbarukan untuk kepentingan generasi mendatang. Untuk memaksimalkan hal tersebut ditindaklanjuti dengan membentuk Peraturan Pemerintah tentang Investasi Dana Migas. Pengembangan energi terbarukan merupakan investasi jangka panjang. Persoalannya adalah bagaimana pengaturan petroleum fund tersebut dapat efektif meningkatkan kesejahteraan rakyat maka tujuh ciri konstitusi tersebut harus menjadi pedoman dalam implementasinya.

Hal ini sangat memungkinkan karena pendapatan migas merupakan salah satu bagian dari 'yang menguasai hajat hidup orang banyak' yang dipergunakan sebesar-besarnya untuk kemakmuran rakyat, salah satunya adalah dengan mengembalikan kepada model investasi publik seperti pendidikan, lingkungan dan kesehatan. Karena bukan sesuatu yang bijak ketika sumber daya migas yang kian menipis hanya dinikmati oleh generasi sekarang tanpa ada investasi untuk generasi yang akan datang.

Pembagian antar generasi dapat dilakukan dengan cara fiskal, hal ini dilakukan Norwegia dengan menginvestasikan penghasilan hidrokarbon pada dana pensiun pemerintah untuk menyebarkan benefit konsumsi kepada generasi selanjutnya. Terutama dengan akumulasi asset yang secara tidak langsung membantu pendanaan benefit pensiun yang dibayarkan oleh sistem jaminan sosial pemerintah. ${ }^{21}$ Karenanya, di dalam naskah akademik RUU migas juga harus dijelaskan mengenai tujuan dasar pengaturan petroleum fund berikut dengan mekanismenya sehingga terdapat gambaran dan pemahaman pada pola/model yang ditawarkan oleh pemerintah dalam pengusahaan dana migas. Perubahan tata kelola juga dapat dilakukan untuk memperkuat peran negara dan pengelolaan migas yang menjamin transparansi. Peran industri penunjang dan partisipasi daerah penghasil juga harus semakin terbuka.

${ }^{21}$ Indah Dwi Qurbani, Mengelola Dana Minyak dan Gas Bumi, Opini Kontan, Senin 13 Agustus 2012. 
3. Mahkamah Konstitusi dalam putusannya telah memberi makna mengenai penguasaan negara dalam Pasal 33 UUD 1945,22 sebagaimana telah dipertimbangkan dalam Putusan Nomor 002/PUU-I/2003, tanggal 21 Desember 2004 mengenai pengujian UU Migas, yang menyatakan bahwa:

“...penguasaan oleh negara dalam Pasal 33 UUD 1945 memiliki pengertian yang lebih tinggi atau lebih luas daripada pemilikan dalam konsepsi hukum perdata. Konsepsi penguasaan oleh negara merupakan konsepsi hukum publik yang berkaitan dengan prinsip kedaulatan rakyat yang dianut dalam UUD 1945, baik di bidang politik (demokrasi politik) maupun ekonomi (demokrasi ekonomi). Dalam paham kedaulatan rakyat itu, rakyatlah yang diakui sebagai sumber, pemilik, dan sekaligus pemegang kekuasaan tertinggi dalam kehidupan bernegara, sesuai dengan doktrin "dari rakyat, oleh rakyat, dan untuk rakyat". Dalam pengertian kekuasaan tertinggi tersebut tercakup pula pengertian pemilikan publik oleh rakyat secara kolektif. Bahwa bumi dan air dan kekayaan alam yang terkandung di dalam wilayah hukum negara pada hakikatnya adalah milik publik seluruh rakyat secara kolektif yang dimandatkan kepada negara untuk menguasainya guna dipergunakan bagi sebesar-besarnya kemakmuran bersama. Karena itu, Pasal 33 ayat (3) menentukan "bumi dan air dan kekayaan alam yang terkandung di dalamnya dikuasai oleh negara dan dipergunakan untuk sebesar-besar kemakmuran rakyat".

Dalam putusan tersebut dipertimbangkan pula bahwa makna "dikuasai oleh negara"

tidak dapat diartikan hanya sebagai hak untuk mengatur, karena hal demikian sudah

dengan sendirinya melekat dalam fungsi-fungsi negara tanpa harus disebut secara khusus dalam Undang-Undang Dasar. Sekiranya pun Pasal 33 tidak tercantum dalam UUD 1945, kewenangan negara untuk mengatur tetap ada pada negara, bahkan dalam negara yang menganut paham ekonomi liberal sekalipun. Inilah yang disebut sebagai terobosan hukum yaitu hukum bukan untuk hukum itu sendiri melainkan dibutuhkan optik yang lebih mampu "menggambarkan" hukum dalam keadaan yang "sebenarnya" dan selengkapnya (the truth about law).

22 Putusan Mahkamah Konstitusi Nomor 36/PUU-X/2012 perihal Pengujian Undang-Undang Republik Indonesia Nomor 22 Tahun 2001 tentang Minyak dan Gas Bumi terhadap Undang-Undang Dasar Negara Republik Indonesia Tahun 1945, hlm; 98. 
4. Berikut ini adalah tabel perbandingan materi muatan antara UU Migas dan RUU Migas.

Tabel 2

Perbandingan Materi Muatan antara UU Migas dan RUU Migas

\begin{tabular}{|c|c|c|}
\hline No. & UU Migas & RUU Migas \\
\hline 1. & Bab I Ketentuan Umum & Bab I Ketentuan Umum \\
\hline 2. & Bab II Asas dan Tujuan & Bab II Asas dan Tujuan \\
\hline 3. & $\begin{array}{l}\text { Bab III Penguasaan dan } \\
\text { Pengusahaan }\end{array}$ & $\begin{array}{l}\text { Bab III Penguasaan dan } \\
\text { Pengusahaan }\end{array}$ \\
\hline 4. & $\begin{array}{l}\text { Bab IV Kegiatan Usaha } \\
\text { Hulu }\end{array}$ & Bab IV Kegiatan Usaha Hulu \\
\hline 5. & Bab V Kegiatan Usaha Hilir & Bab V Kegiatan Usaha Hilir \\
\hline 6. & Bab VI Penerimaan Negara & Bab VI Penerimaan Negara \\
\hline 7. & $\begin{array}{l}\text { Bab VII Hubungan } \\
\text { Kegiatan Usaha Migas } \\
\text { dengan Hak Atas Tanah }\end{array}$ & $\begin{array}{l}\text { Bab VII Badan Pengusahaan } \\
\text { Minyak dan Gas Bumi }\end{array}$ \\
\hline 8. & $\begin{array}{l}\text { Bab VIII Pembinaan dan } \\
\text { Pengawasan Badan } \\
\text { Pelaksana dan Badan } \\
\text { Pengatur }\end{array}$ & Bab VIII \\
\hline 9. & $\begin{array}{l}\text { Bab IX Pembinaan dan } \\
\text { Pengawasan }\end{array}$ & $\begin{array}{l}\text { Bab IX Hubungan Kegiatan Usaha } \\
\text { Migas dengan Hak Atas Tanah }\end{array}$ \\
\hline 10. & Bab X Penyidikan & Bab X Pembinaan dan Pengawasan \\
\hline 11. & Bab XI Ketentuan Pidana & Bab XI Larangan \\
\hline 12. & $\begin{array}{l}\text { Bab XII Ketentuan } \\
\text { Peralihan }\end{array}$ & Bab XII Penyidikan \\
\hline 13. & Bab XIII Ketentuan Lain & Bab XIII Ketentuan Pidana \\
\hline 14. & $\begin{array}{l}\text { Bab XIV Ketentuan } \\
\text { Penutup }\end{array}$ & Bab XIV Ketentuan Peralihan \\
\hline
\end{tabular}




\begin{tabular}{|l|l|l|}
\hline 15. & Bab XV Ketentuan Penutup \\
\hline
\end{tabular}

Sumber : UU No. 22 Tahun 2001 tentang Migas dan Draft RUU Perubahan UU Migas, awal persidangan 2012 disusun oleh tim PUU Setjen DPR RI atas penugasan dari Komisi VII DPR RI.

\section{Penutup}

Perubahan atas UU migas harus berlandaskan pada konstitusi dan memuat perubahan terhadap tata kelola migas yang transparan untuk memperkuat peran negara dalam mensejahterakan rakyat. Negara sebagai representasi rakyat dalam pengelolaan migas harus memiliki keleluasaan membuat peraturan yang membawa manfaat bagi sebesar-besarnya kemakmuran rakyat.

Substansi pokok dalam Perubahan atas UU migas adalah pengelolaan dan pengusahaan dana migas digunakan untuk penggantian cadangan migas dan pengembangan energi terbarukan untuk kepentingan generasi mendatang. Pengelolaan migas yang menjamin transparansi adalah sesuatu yang wajib.

\section{Daftar Pustaka}

Butt, Simon dan Fritz Edward Siregar. 2013. "Analisis Kritik Terhadap Putusan Mahkamah Konstitusi Nomor 36/PUU-X/2012." Mimbar Hukum, Vol. 25, Nomor 1, Februari 2013.

Dewan Perwakilan Rakyat Republik Indonesia. Rancangan Undang-Undang tentang Perubahan Atas Undang-Undang Nomor 22 Tahun 2001 tentang Minyak dan Gas Bumi.

Econit Advisory Group. Paper No. 34 tanggal 31 Maret 1999. http://www.detik.com

H.C.B., Dharmawan dan Al Soni (Ed.). 2005. BBM Antara Lahan Hidup dan Lahan Korupsi. Jakarta: Penerbit Buku Kompas, Jakarta.

Husna, Cut Asmaul. 2012. “Implikasi Putusan Mahkamah Konstitusi Terhadap Regulasi Production Sharing Contract." Jurnal Konstitusi, Volume 9 Nomor 4, Desember 2012.

Ibrahim, Johnny. 2007. Teori dan Metodologi Penelitian Hukum Normatif. Malang: Bayumedia. 
Indonesia (1). Undang-undang Tentang Minyak dan Gas Bumi. UU No. 22 Tahun 2001. Lembaran Negara Tahun 2001 Nomor 136 Tambahan Lembaran Negara Nomor 4152.

(3). Undang-Undang Tentang Perusahaan Pertambangan Minyak Negara (Pertamina). UU No. 8 Tahun 1971. Lembaran Negara Tahun 1971 Nomor 76, Tambahan Lembaran Negara Nomor 2971.

(2). Undang-Undang Tentang Pertambangan Minyak dan Gas Bumi. UU No. 44 Prp Tahun 1960. Lembaran Negara Tahun 1960 Nomor 133, Tambahan Lembaran Negara Nomor 2070.

Justice for The Poor Team, The World Bank. 2004. Menciptakan Peluang Keadilan: Laporan Atas Studi Village Justice in Indonesia dan Terobosan dalam Penegakan Hukum di Tingkat Lokal. Jakarta: World Bank.

Mahkamah Konstitusi Republik Indonesia (1). Putusan Mahkamah Konstitusi Nomor 36/PUU-X/2012 perihal Pengujian Undang-Undang Republik Indonesia Nomor 22 Tahun 2001 tentang Minyak dan Gas Bumi terhadap Undang-Undang Dasar Negara Republik Indonesia Tahun 1945.

(2). Putusan Mahkamah Konstitusi Nomor 20/PUU-V/2007 perihal Pengujian Undang-Undang Republik Indonesia Nomor 22 Tahun 2001 tentang Minyak dan Gas Bumi terhadap Undang-Undang Dasar Negara Republik Indonesia Tahun 1945.

(3). Putusan Mahkamah Konstitusi Nomor 002/PUU-I/2003 perihal Pengujian Undang-Undang Republik Indonesia Nomor 22 Tahun 2001 tentang Minyak dan Gas Bumi terhadap Undang-Undang Dasar Negara Republik Indonesia Tahun 1945.

Marzuki, Peter Mahmud. 2007. Penelitian Hukum. Jakarta: Kencana.

Naskah Akademik Rancangan Undang-Undang tentang Perubahan Atas Undang-Undang Nomor 22 Tahun 2001 tentang Minyak dan Gas Bumi.

Nugroho, Hanan. 2004. Deregulasi Setengah Hati: Tinjauan Terhadap Restrukturasi Sektor Energi Indonesia. Dibawakan dalam Seminar Akademik Tahunan Ekonomi I, Pasca Sarjana Ekonomi Universitas Indonesia \& Ikatan Sarjana Ekonomi Indonesia, Jakarta, 8-9 Desember 2004.

Qurbani, Indah Dwi (1). 2003. Proses Terbentuknya Undang-Undang Nomor 22 Tahun 2001 tentang Minyak dan Gas Bumi dalam Prespektif Politik Demokratis. Skripsi Program Sarjana Fakultas Hukum Universitas Muhammadiyah Malang.

(2). 2012. Mengelola Dana Minyak dan Gas Bumi. Opini Kontan, Senin 13 Agustus 2012. 
(3). 2012. Politik Hukum Pengelolaan Minyak dan Gas Bumi di Indonesia. Arena Hukum Jurnal Ilmu Hukum Universitas Brawijaya, Volume 6, Nomor 2, Agustus 2012.

Rahardjo, Satjipto. 2005. "Pokok-Pokok Pikiran Memberantas Korupsi Secara Progresif," dibawakan dalam Anti Corruption Summit, Badan Kerjasama Fakultas Hukum Seluruh Indonesia, Universitas Gajah Mada, Yogyakarta, 11-13 Agustus 2005.

Rangkuti, Zulkifli dan Untung Suryanto. 2012. Pemanfaatan Dana Migas (Migas Fund) untuk Ketahanan energi (Energy Security) sebagai alternatif Pengembangan Industri Hulu (UpStream) Migas Nasional. http://works.bepress.com/drzulkifli_rangkuti/10.

Stiglitz, Joseph E. 2007. “Menjadikan Sumber Daya Alam Sebagai Berkah, Bukan Kutukan" dalam Svetlana Tsalik (Ed.), Covering Oil. New York: Pantau Open Society Institute.

Tjakrawerdaja, Subiakto. 2008. "Menunggu UU Induk Mengenai Perekonomian Nasional." Reform Review (Jurnal untuk Kajian dan Pemetaan Krisis), Volume II No. 1 April-Juni 2008. 